\title{
Evaluation of accelerated carbonation curing in cement- bonded balsa particleboard
}

\author{
Matheus Roberto Cabral 1 Erika Yukari Nakanishi • Valdemir dos Santos • \\ Christian Gauss $\cdot$ Sérgio Francisco dos Santos $\cdot$ Juliano Fiorelli
}

Received: 24 November 2017 / Accepted: 21 March 2018/Published online: 23 March 2018

(C) RILEM 2018

\begin{abstract}
This study aimed to assess the potential usage of balsa wood to produce cement-bonded particleboards as well as to study the effects of accelerated carbonation on the cement-bonded balsa particleboard. Particleboards were subjected to two different curing conditions, (1) conventional curing: control—curing for $48 \mathrm{~h}$ in a climatic chamber, followed by 25 days in a saturated environment $(98 \pm 2 \%)$ in sealed plastic bags at $23{ }^{\circ} \mathrm{C}$, (2) accelerated carbonation-curing for $48 \mathrm{~h}$ in a climatic chamber, and then in environment with $\mathrm{CO}_{2}(24 \mathrm{~h}$ concentration of $15 \%$ ), followed by 24 days in a saturated environment $(98 \pm 2 \%)$ in sealed plastic bags at $23{ }^{\circ} \mathrm{C}$. After 28 days of curing, the particleboards degree of carbonation was evaluated by TGDTG and XRD analysis. Thermal, physical and mechanical characterizations were conducted following the recommendations of ASTM-E1530 and DIN: $310,322,323$ standards, respectively. Accelerated carbonation decreased the portlandite content and increased of calcium carbonate content of the studied
\end{abstract}

M. R. Cabral ( $₫)$ · E. Y. Nakanishi ·

V. dos Santos - C. Gauss - J. Fiorelli

Department of Biosystems Engineering, University of Sao

Paulo, Pirassununga, SP, Brazil

e-mail: matheusrc@usp.br

S. F. dos Santos

Department of Materials and Technology, School of Engineering, Sao Paulo State University, Guaratinguetá, SP, Brazil particleboards. Thermal properties showed that the particleboards could be used as an insulation material in accordance to European Standard (BS EN 13986). Physical and mechanical properties of the studied materials showed that they are potential building particleboard, because this material satisfied the requirements of ISO 8335 standard.

Keywords Accelerated carbonation · Forestry products · Wood · Portland cement $\cdot$ Cement composites

\section{Introduction}

Cement-bonded particleboard as building material is already known in many countries, such as the USA, Canada, Germany, Japan, France, Denmark, Austria, Switzerland, Belgium, Mexico, Finland, Russia, China, and Australia. The potential expansion of this composite has been related to the production of a more durable building material, when compared to organic particleboards [1].

Cement-bonded particleboards are wood or nonwood composites bonded by an inorganic matrix, where the Portland cement (PC) is the usual binder, due to its physical and mechanical performance and global availability [2]. To produce cement-bonded particleboard, wood or non-wood raw material introduction can range from 30 to $70 \%$ by weight and this 
introduction is mainly associated to increase modulus of rupture (MOR), to improve thermal and sound insulation properties of the composites [1,2].

Furthermore, PC as binder of cement-bonded particleboard provides superior properties compared to those organic particleboards, providing better resistance to humidity, heat and fungal attack. Therefore, cement-bonded particleboards are a potential replacing for traditional building materials for internal and external applications [2].

However, given the popular use of raw material from slow-growing forests to produce cement-bonded particleboards, the search for alternative vegetal raw materials to decrease the negative environmental impact is crucial. Alternative vegetal raw materials like agricultural residues, low grade wood species and non-wood materials were used significantly to produce cement-bonded particleboards around the world by several studies, such as kenaf [3], sunflower [4], eggplant [5] maize [6] cotton [7], arhar [8], and poplar [9].

Balsa (Ochroma pyramidale) is a fast-growing tropical tree from South America, and it is one of the lightest and strongest of all commercial woods. This wood can reach about $20 \mathrm{~m}$ in height and $75 \mathrm{~cm}$ in diameter in just 5 years [10]. Balsa is basically composed of three biopolymers: cellulose, hemicellulose and lignin. Additionally, a very low content of extractives have been reported [10].

Due to the low extractives content of balsa ( $1 \%$ by mass) in comparison to other woods (higher than $8 \%$ by mass) [10], [11], and the high crystallinity of its cellulose (around 90\%) which can provide better mechanical properties, dimensional stability, chemical resistance, balsa can represent a great alternative raw material to produce cement-bonded particleboards [12].

Although, the cement-bonded particleboard presents higher durability in comparison to other particleboards, the major disadvantage of this composite is the mineralization of the vegetable raw materials in the high alkalinity of the PC, which also led to degradation of their constituents. The mineralization process of the vegetable raw materials causes their embrittlement and it can diminish the physical and mechanical properties over time of the cement-bonded particleboard [13].

In the light of the above facts, the accelerated carbonation curing could be used to obtain a more stable and durable cement-bonded particleboard, as well as the higher density of calcium carbonate in the interfacial transition zone between wood chips and cement matrix can provide a better chemical stability and mechanical properties [14, 15].

Accelerated carbonation curing can be described as a diffusion of $\mathrm{CO}_{2}$ through the pores of the cement matrix. The $\mathrm{CO}_{2}$ is dissolved in the aqueous phase, releasing $\mathrm{CO}_{3}{ }^{2-}$ ions and thus transformed into carbonic acid $\left(\mathrm{H}_{2} \mathrm{CO}_{3}\right)$. Moreover, portlandite $\left[\mathrm{Ca}(\mathrm{OH})_{2}\right]$ is dissociated into $\mathrm{Ca}^{2+}$ and $(\mathrm{OH})^{-}$. The dissolved $\mathrm{CO}_{2}$ reacts with portlandite, resulting in precipitation of calcium carbonate $\left(\mathrm{CaCO}_{3}\right)$. The mechanism of reaction mentioned above occurs making a reduction of the $\mathrm{pH}$ (ranging from 11 to 8 ) and the porosity of the cementitious matrix is decreased, providing better chemical stability, physical and mechanical properties [14, 16-18].

Therefore, the objectives of this study were (a) to assess the potential usage of balsa to produce cementbonded balsa particleboard and (b) to evaluate the effects of the accelerated carbonation curing in cement-bonded balsa particleboard, by means of chemical, thermal, physical analysis and mechanical tests.

\section{Materials and methods}

\subsection{Materials}

PC(CPV-ARI), with high early strength, according to the Brazilian Normative-NBR 5733 standard [19] and equivalent to PC Type III ASTM C150 was used. Balsa used in this study was obtained in a wood processing company in the state of São Paulo, Brazil.

\subsection{Balsa processing}

Initially, the balsa was dried in an oven with forced ventilation at $60{ }^{\circ} \mathrm{C}$ for $72 \mathrm{~h}$. The dried wood was then chopped using a knife mill (Model DPC-1, Cremasco, Brazil) and after that it was separated in a vibrating screen (Model G, Produtest, Brazil) to obtain chips of $8 \mathrm{~mm}$. 


\subsection{Balsa characterization}

\subsubsection{Chemical composition}

Balsa chips were subjected to analysis to determine their chemical composition, such as cellulose and hemicellulose [20], lignin (Tappi T 222 om) [21] and extractives contents (Tappi T $204 \mathrm{~cm}$ method) [22].

\subsubsection{X-Ray diffraction}

X-Ray Diffraction (XRD) analysis was conducted to calculate the crystallite size of the balsa chips. To prepare $1 \mathrm{~mm}$ balsa samples, a Wiley mill (Model 4, Thomas Scientific, USA) was used, subsequently the samples were oven-dried $\left(60{ }^{\circ} \mathrm{C}, 24 \mathrm{~h}\right)$.

XRD analysis was evaluated in an AXS Analytical X-ray diffractometer (Model MiniFlex 600, Rigaku, Japan), operated at $40 \mathrm{kV}$ and $15 \mathrm{~mA}$, with $\mathrm{Cu}-\mathrm{K} \alpha$ radiation $(\lambda$ : $1.54056 \AA)$. Standardized test: with a scanning from $5^{\circ}$ to $40^{\circ}(2 \theta)$ at $1 \% \mathrm{~min}$. No background correction was used. The measurement of the crystallite size was performed by using the Scherrer equation as described by Wilson and Langford [23], according to Eq. (1).

$D=\frac{K \lambda}{\beta \cos \theta}$

where $D=$ perpendicular size to the lattice plane represented by the peak (200); $k=$ constant related to the shape of the crystallites and the reflecting index planes; $\lambda=$ wavelength experiment obtained of the beam diffraction; $\beta=$ peak width at half maximum (pwhm) in radians and $\theta=$ position of the peak (half of the plotted $2 \theta$ value).

XRD crystalline and amorphous patterns were evaluated by using the pwhm of the Mercury 3.7 program (http://www.ccdc.cam.ac.uk/products/ mercúio) [24], following the method proposed by Nam et al. [25]. The crystal information files were simulated by the published coordinates of the asymmetric units of cellulose $I \beta$, once that this cellulose is the most abundant in nature [25].

The coordinates were taken from the crystal information files according to Nishiyama et al. [26] method. The less-perfectly ordered cellulose (amorphous), as the cellulose $I \alpha$ [25], and the calculated amorphous fraction was created by using a pwhm of 9.0 for the cellulose II pattern calculated. The cellulose $I \beta$ file was edited with Peak fit with a parameter, $a=7.784 \AA$ for $I \beta$ unit cell to $8.12 \AA$, cell angle $\gamma$ from $96.55^{\circ}$ to $94.55^{\circ}$ and saved as a crystal information file extension.

\subsubsection{Morphological characterization}

Morphological characterization of the balsa chips (oven-dried at $60{ }^{\circ} \mathrm{C}, 24 \mathrm{~h}$ ) without a metallic coating and without epoxy resin impregnation was evaluated in a Scanning Electron Microscope (SEM), model TM-3000, Hitachi, Japan at $15 \mathrm{kV}$ (accelerating voltage).

SEM images were generated by using backscattered electron mode in different fields; magnifications $(100 ; 500 ; 1000$ and $3000 \times)$ with a working distance (WD) of $5.90 \mathrm{~mm}$. Around 100 SEM images were obtained from 25 different samples for each magnification. However, just the typical images of each magnification were used in this manuscript. Therefore, the main cell types identified from the balsa chips have been evaluated.

\subsection{Production of cement-bonded balsa particleboards}

Cement-bonded balsa particleboards were manufactured with the target density of $1250 \mathrm{~kg} / \mathrm{m}^{3}$ and a thickness of $10 \mathrm{~mm}$. Balsa chips with humidity of $8 \%$ were used. The formulation of the cement-bonded balsa particleboards adopted were $30 \%$ by mass of balsa chips and $70 \%$ by mass of PC. The amount of water added was calculated by using the Eq. (2) applied by Hachmi et al. [27].

$\mathrm{WL}=0.35 C+(0.30-\mathrm{WHC}) w$

where $\mathrm{WL}$ is the volume of water added to the mixture (L), $C$ is the quantity of PC (kg); WHC is the wood humidity content (oven-dry basis) (kg).

Firstly, balsa chips were inserted in a planetary mixer and subsequently the measured quantity of water was added using a spraying nozzle. Then, PC was added into the planetary mixer and the mixture was homogenized for $5 \mathrm{~min}$ to prevent agglomerations.

After the homogenization, the mixture was manually placed and evenly distributed in a wooden forming box $(300 \mathrm{~mm} \times 300 \mathrm{~mm})$ and pre-pressed. The pre-pressed mass was placed into hydraulic press (Model PHH100T, Hidral-Mac ${ }^{\circledR}$, Brazil) and then 
applied pressure of $3 \mathrm{MPa}$ for $24 \mathrm{~h}$ in a room temperature. A final thickness of cement-bonded balsa particleboard was $10 \pm 0.1 \mathrm{~mm}$, and in total 30 particleboards, 15 per each curing process were produced.

\subsection{Curing condition}

The studied cement-bonded balsa particleboards were subjected to two curing processes (control and accelerated carbonation). The main reason to use two curing conditions in this study was to evaluate the effects of the accelerated carbonation curing on the cement-bonded balsa particleboard.

\subsubsection{Control curing}

Cement-bonded balsa particleboards that were not subjected to the accelerated carbonation curing (conventional curing: control) were maintained in a controlled environment (temperature of $60{ }^{\circ} \mathrm{C}$, relative humidity of $90 \%$ ) for $48 \mathrm{~h}$ in a climatic chamber (Model EPL4H, Espec Corporation. USA) and then stored in a saturated environment $(98 \pm 2 \%)$ in sealed plastic bags at $23{ }^{\circ} \mathrm{C}$ for 25 days.

\subsubsection{Accelerated carbonation curing}

Accelerated carbonation curing parameters according to the procedures described by Cabral et al. [28] and performed in a climatic chamber (Model EPL4H, Espec Corporation. USA). After maintaining the cement-bonded balsa particleboards for $48 \mathrm{~h}$ in a controlled environment at $60{ }^{\circ} \mathrm{C}$ and $90 \%$ relative humidity, $\mathrm{CO}_{2}$ (15\% concentration) was added for $24 \mathrm{~h}$. The parameters chosen for the accelerated carbonation (i.e. temperature, relative humidity, $\mathrm{CO}_{2}$ concentration and maintaining the composites before $\mathrm{CO}_{2}$ introduction) were based on previous studies conducted for the fiber cement composites [13] and cement-bonded sugarcane bagasse fibers [28]. The completion of the curing process was done in a saturated environment $(98 \pm 2 \%)$ at $23{ }^{\circ} \mathrm{C}$ (in sealed plastic bags) for 24 days.

\subsection{Curing conditions evaluation}

\subsubsection{Thermal and mineralogical evaluation}

Samples of cement-bonded balsa particleboards produced with different curing conditions (control and carbonated) were evaluated in terms of their phase composition. For this purpose, the thermogravimetric technique (TG) and XRD analyses were conducted.

TG analysis performed in a TG/DSC thermal analyzer (Model STA449 F3 Jupiter ${ }^{\circledR}$, Netzch. Germany) with nitrogen gas atmosphere $(50 \mathrm{~mL} / \mathrm{min})$. Standardized test: from 25 to $1000{ }^{\circ} \mathrm{C}$ and heating rate of $10{ }^{\circ} \mathrm{C} / \mathrm{min}$. The identification of portlandite and calcium carbonate peaks was realized from the weight loss measured in the TG-DTG curves.

To estimate the amount of portlandite and calcium carbonate the stoichiometry calculations using the molar mass balance method was used, as suggested by Borges et al. [17]. Considering that 74, 44, 100 and $18 \mathrm{~g} / \mathrm{mol}$ are the molar masses of Portlandite, dioxide carbon, calcium carbonate and, $\mathrm{H}_{2} \mathrm{O}$, respectively. The TG curves as well as the derivative thermogravimetry (DTG) curves were used to inspect the nature of hydration products formed in the cement-based systems.

XRD analyses were performed in Analytical X-ray diffractometer (Model MiniFlex 600, Rigaku, Japan), operated at $40 \mathrm{kV}$ and $15 \mathrm{~mA}$, with $\mathrm{Cu}-\mathrm{K} \alpha$ radiation $\left(\lambda: 1.54056 \AA\right.$ ), in $2 \theta$ range from $5^{\circ}$ to $65^{\circ}$ and scan speed of $10 \% \mathrm{~min}$. To identify and quantify the crystalline phases of the control and carbonated particleboards, the phase indexing and quantification was conducted by the Rietveld method, using the software Highscore $\subset$ 3.0, Panalytical. The refinement shown in this work was carried out without the addition of an internal standard and therefore, only the crystalline phases were quantified and normalized to $100 \%$.

The preparation of powdered samples for the analyses (TG/DTG, XRD) followed the procedures indicated by Mohr et al. [29], the samples of PC were extracted carefully from the control and carbonated cement-bonded balsa particleboards (28 days). To stop the cement hydration process, the samples were immersed in isopropyl alcohol for $10 \mathrm{~h}$, they were subsequently dried at $40{ }^{\circ} \mathrm{C}$ for $5 \mathrm{~min}$, milled and passed through sieve $(0.106 \mathrm{~mm})$, sealed in microtubes $(2 \mathrm{~mL})$ and stored until test time. 
2.7 Cement-bonded balsa particleboards characterization

\subsubsection{Thermal-physical-mechanical characterization}

Thermal conductivity tests were performed in thermal conductivity meter (Model DTC 300, TA Instruments, USA). For each curing condition, 20 specimens with diameter of $50 \mathrm{~mm}$ were analyzed according to the ASTM E1530 Standard [30] adapted. Each specimen was accommodated between two devices (hot and cold plates) with a temperature difference of $30^{\circ} \mathrm{C}$. To conduct this test, specimens were conditioned at $23{ }^{\circ} \mathrm{C}$ and $60 \%$ of relative humidity for $24 \mathrm{~h}$.

Physical testing of the water absorption (WA), thickness swelling (TS) after $24 \mathrm{~h}$ of immersion in water and apparent density (AD) of the cementbonded balsa particleboards followed the procedures established by the Wood based particleboards EN 322 [31] and EN 323 [32] standards. To obtain each physical property 40 specimens (28 days) were tested with a nominal dimension of $50 \mathrm{~mm} \times 50 \mathrm{~mm} \times 10$ $\mathrm{mm}$ for each curing condition.

Mechanical tests in equilibrium with the temperature and air humidity of the laboratory were performed in the cement-bonded balsa particleboards (28 days), using the mechanical testing machine, Emic, Model DL 30000, Illinois Tool Works, USA. Prismatic specimens were prepared using a diamond saw blade, having nominal dimensions of $250 \mathrm{~mm} \times 50 \mathrm{~mm} \times$ $10 \mathrm{~mm}$. Thereafter preparing, the mechanical specimens were conditioned at $23{ }^{\circ} \mathrm{C}$ and $60 \%$ of relative humidity for $24 \mathrm{~h}$. The three-point bending test configuration with a span of $200 \mathrm{~mm}$ was used to determine the mechanical the properties of $40 \mathrm{spec}-$ imens of each curing condition. Modulus of rupture (MOR) and modulus of elasticity (MOE) were determined at a cross-head speed of $7 \mathrm{~mm} / \mathrm{min}$ according to recommendations of EN 310 [33].

The modulus of rupture (MOR) and modulus of elasticity (MOE) were calculated using Eqs. (3) and (4), respectively.

$\mathrm{MOR}=\frac{3 F_{\max } L}{2 b t^{2}}$

where MOR is in MPa; $F_{\text {max }}$ is maximum load, in N; $L_{1}$ is span length, in mm; $b$ is width of the sample, in $\mathrm{mm} ; t$ is thickness of the sample, in $\mathrm{mm}$.
$\mathrm{MOE}=\frac{L_{1^{3}}^{3}\left(F_{2}-F_{1}\right)}{4 b t^{3}\left(a_{2}-a_{1}\right)}$

where MOE is in MPa; $L_{1}$ is span length, in $\mathrm{mm} ; F_{2}$ and $F_{1}$ are loads, in MPa; $b$ is width of the samples, in $\mathrm{mm} ; t$ is thickness of the samples, in mm; $a_{2}$ and $a_{1}$ are deflections at the mid-length of the samples.

\subsection{Statistical analysis}

Tukey test with a significance level of 5\% was conducted using the software SAS version 2.5.1 to analyze the difference between mean values of the thermal, physical and mechanical properties of the particleboards with different curing procedures. For the results of the Tukey test, the letter " $a$ " denotes the group with the higher mean value while the letter " $b$ " denotes the group with lower mean value.

\section{Results and discussion}

\subsection{Balsa characterization}

\subsubsection{Chemical composition}

Wood chemical composition is one of the most important aspects affecting the compatibility with cement [34]. Table 1 presents the contents of cellulose, hemicellulose, lignin and extractives of the balsa used in this study.

It has been noticed that the cellulose is the main compound of the balsa (Table 1). This characteristic is an important factor, because cellulose, primarily acts as reinforcement and reduces the fragility of wood. Studies conducted by Malek and Gibson [35] for the balsa chemical composition reported mean value of $43.93 \%$ cellulose, $28.65 \%$ hemicellulose and $27.42 \%$ lignin. In addition, Borrega et al. [10] found the mean value about $2 \%$ of extractives for balsa. It is noteworthy that the chemical contents of the studied balsa (Table 1) are similar to those results obtained in the literature for the chemical contents of cellulose, hemicellulose, lignin and extractives of the balsa.

In general, wood species that are commonly used to produce cement-bonded particleboards contain about $50 \%$ cellulose, $30 \%$ hemicelluloses and $25 \%$ lignin [11]. Fiorelli et al. [36] studied the chemical composition of softwood (Pinus) and found values about 
Table 1 Balsa chemical composition (Standard deviation in parentheses)

\begin{tabular}{lllllll}
\hline & Cellulose $(\%)$ & Hemicellulose $(\%)$ & Lignin $(\%)$ & Extractives $(\%)$ & Ash (\%) & Humidity (\%) \\
\hline Balsa & $53.02(0.2)$ & $28.24(0.3)$ & $15.10(0.2)$ & $1.82(0.1)$ & $1.82(0.1)$ & $8.23(0.2)$ \\
\hline
\end{tabular}

Each value represents the mean of three replicates

$51.13 \%$ cellulose $27.29 \%$ hemicellulose and $15.10 \%$ lignin.

According to Fan et al. [37] the PC hydration temperature was reduced by inhibitory substances, such as the extractives. Extractives consists of sugars, tannins, gums, starches, colorings, fats, resins and low molecular weight carbohydrates, which can be removed with hot or cold water, or organic solvents. The high content of extractives causes a decrease in the PC hydration temperature, due to the dissolution of these components in the aqueous medium, which results in protective layer formation in the cement grains and prevents the water from reaching the grains for subsequent hydration [38, 39]. On the other hand, the low extractives content of the balsa used in this study $(1.82 \%)$ in comparison to other wood species (higher than $8 \%$ ) $[10,11]$ as well as the cellulose, hemicelulose and lignin contents similar to those found literature could allow the balsa as an interesting constituent for cement-bonded particleboards.

\subsubsection{X-ray diffraction}

Woods are composed of a complex network of three biopolymers: cellulose (semi crystalline), hemicellulose (amorphous) and the lignin (aromatic polymer) [40].

Therefore, the crystallite size measurement of the cellulose can be a good parameter to evaluate the crystalline portion of cellulose regarding the total amount of cellulose. As an important indicator of the structure and certain properties of the cellulose, crystallite size can also be an indicator of the hardness of wood. Moreover, the highest crystallite size can represent a decrease in water absorption, wet expansion, chemical resistance, dimensional stability, higher density and stiffness $[11,12]$. The cellulose crystallite size was evaluated by using the experimental, theoretical diffraction standard and by using crystal information files from the Mercury program 3.7.

Figure 1 shows the balsa XRD. The peak width at half maximum (pwhm) of 2.5 was used to adjust the theoretical model of the semi-crystalline cellulose for the experimental model of balsa (Fig. 1a, b). The theoretical diffraction pattern was adjusted according to the crystallographic information of crystalline cellulose by using pwhm of $0.1 \mathrm{rad}$ [24].

Figure $1 \mathrm{~b}$ indicates the relative quantity of amorphous and crystalline phases of the balsa. It was evidenced the content of $84 \%$ of crystalline cellulose while the amorphous cellulose was of $16 \%$.

Considering that the cellulose content in balsa was $53.02 \%$ (Table 1), then cellulose crystallinity was about $84 \%$, significantly higher than the $40-60 \%$ determined for softwoods and hardwoods [41, 42]. The crystallite size values on Table 2 corroborate this assumption.

Table 2 shows the crystallite size of balsa compared to other vegetal materials.

The balsa crystallite size (Table 2) is much higher than those observed in the literature, such as Andersson et al. [43], who reported crystallite size value of $32 \AA$ for Norway spruce and $31 \AA$ for Scots pine. Penttilä et al. [42] reported birch sawdust crystallite size of $32 \AA$, Correia et al. [44] conducted a studied of the crystallographic characteristics of bamboo pulps and found a crystallite size of $40 \AA$.

An investigation conducted by Borrega et al. [10] found the crystallinity of balsa about 80-90\%. Andersson et al. [43] investigated the crystallinity of Norway spruce and values ranged from 23 to $32 \%$, while the values for the Scots pine ranges from 24 to $31 \%$.

\subsubsection{Microstructural analysis}

Balsa chips microstructure was characterized by means of the analysis of 60 SEM images from 20 different balsa chips. Figure 2 shows representative micrographs of the balsa, in which it was possible to observe the presence of vessels and a cellular structure in the surface.

The main cell types identified from the transversal section of balsa image analysis were vessels and fibers 

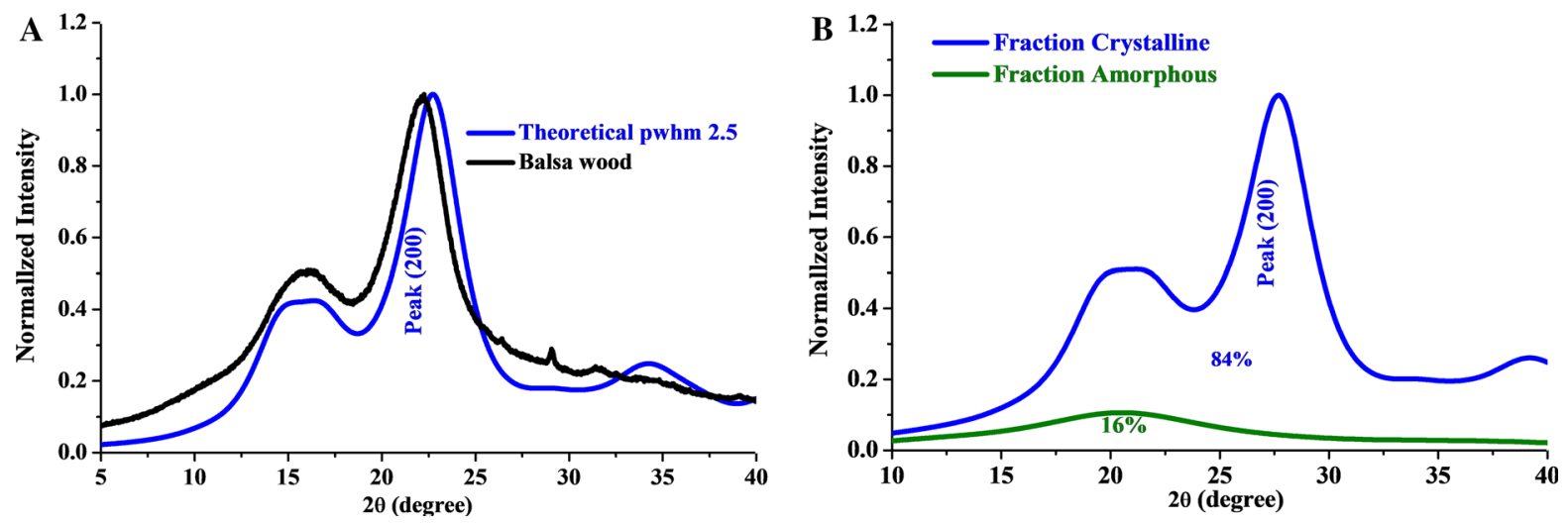

Fig. 1 X-ray diffraction patterns for balsa: a balsa theoretical and experimental model, b amorphous and crystalline fraction

Table 2 Cellulose crystallite size of balsa compared to other previous studies

\begin{tabular}{ll}
\hline Sample & Crystallite size $(\AA)^{*}$ \\
\hline Studied balsa & 94 \\
Norway spruce [43] & 32 \\
Scots pine [43] & 31 \\
Birch sawdust [42] & 32 \\
Bamboo pulp [44] & 40 \\
\hline
\end{tabular}

*Calculated using the Scherrer equation

(Fig. 2a). The observed vessels and fibers have a polygon form and are elongated in the transverse direction (Fig. 2b). According to Borrega and Gibson [45], the mechanical strength of balsa is correlated with its tridimensional structure. As can be seen in Fig. 2, the growth vessels and fibers can be identified and the anatomy of the cells is like the behavior of a honeycomb when submitted to a planar load.

Moreover, the morphology of balsa can be an interesting aspect to produce cementitious composites. Because the cement during composites production in its fresh phase fill in the voids and creates anchorage between the reinforcement phase and the matrix.

\subsection{Degree of carbonation of the cement-bonded balsa particleboards}

\subsubsection{TG-DTG and XRD}

Figure 3 shows the TG-DTG plots of the cementbonded balsa particleboards samples of control and carbonated (after 28 days of final curing).
At the DTG curve of the four peaks can be observed, as indicated in Fig. 3a. The peak 1 (Fig. 3a), from 95 to $200{ }^{\circ} \mathrm{C}$, is related to the thermal decomposition of the hydrated calcium silicate $(\mathrm{CSH})$ and ettringite $[46,47]$. The peak 2 (Fig. 3a) is related to the thermal decomposition of the balsa remnants in the cement powder, corroborating with the TG-DTG results for balsa of the Fig. 3b.

The thermal decomposition of portlandite $(\mathrm{CH})$ occurs from 400 to $500{ }^{\circ} \mathrm{C}$ (peak 3 ) and in this region, it was evidenced that the $\mathrm{CH}$ has been completely consumed by the formation of calcium carbonate in the carbonated cement-bonded balsa sample.

In the control sample (Fig. 3a), the thermal decomposition of poorly crystallized calcium carbonate was observed from 650 to $750{ }^{\circ} \mathrm{C}$ (peak 4). While in the carbonated sample, a higher loss of mass was noticed in the peak 4 (Fig. 3a), which can be related to the decomposition of well-crystallized calcium carbonate, as reported by Rostami et al. [46] and Pizzol et al. [48].

Table 3 shows the estimated percentages of calcium carbonate and portlandite of the particleboards obtained by the stoichiometry calculation.

Indeed, the accelerated carbonation reaction provides the increase in volume of material in the interior of the composite, that is, for every mole of portlandite, (molar volume $33 \mathrm{~mL}$ ) consumed, 1 mole of calcium carbonate (molar volume of $36.9 \mathrm{~mL}$ ) is generated, which corresponds to a volume increase of $11.8 \%$ solids [16].

This reaction was observed with the increase of calcium carbonate content of the carbonated particleboards (from 20.9 to $38.4 \%$, Table 3). Accelerated carbonation is applied immediately after casting, then, 


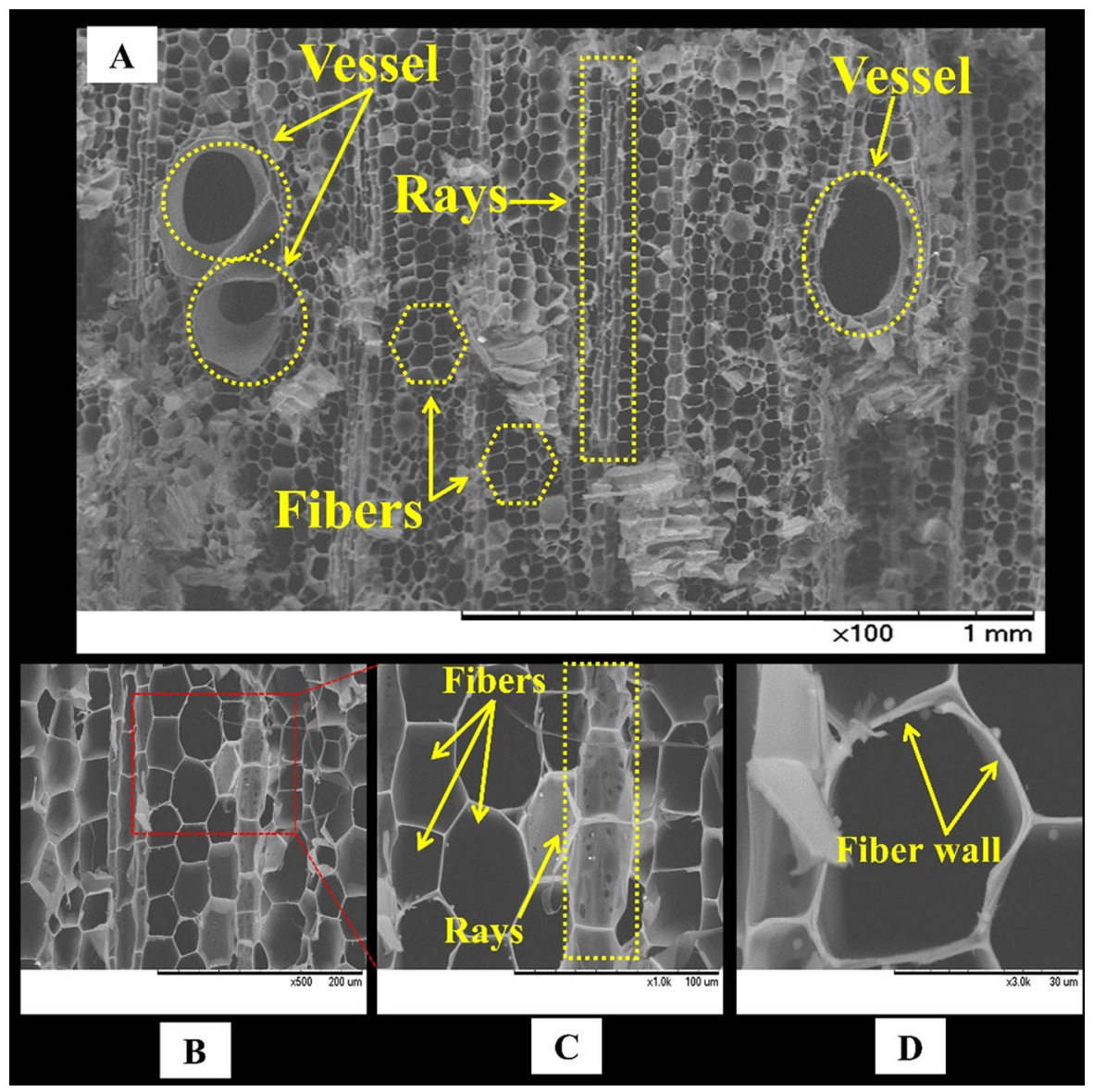

Fig. 2 SEM micrographs of balsa chip surface: a cross section of balsa chips showing the main type of cells $\mathbf{b}$ details of the cells $\mathbf{c}$ zoom to the fibers and rays $\mathbf{d}$ fiber wall

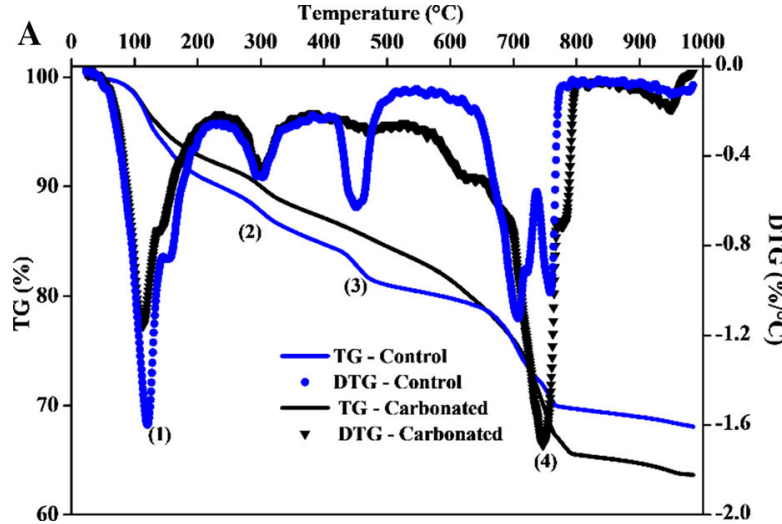

Fig. 3 TG-DTG curves: a cement-bonded balsa b balsa

$\mathrm{CO}_{2}$ can chemically react with the silicate phases, mainly dicalcium silicate, tricalcium silicate. However, after the hydration process, the $\mathrm{CO}_{2}$ can react

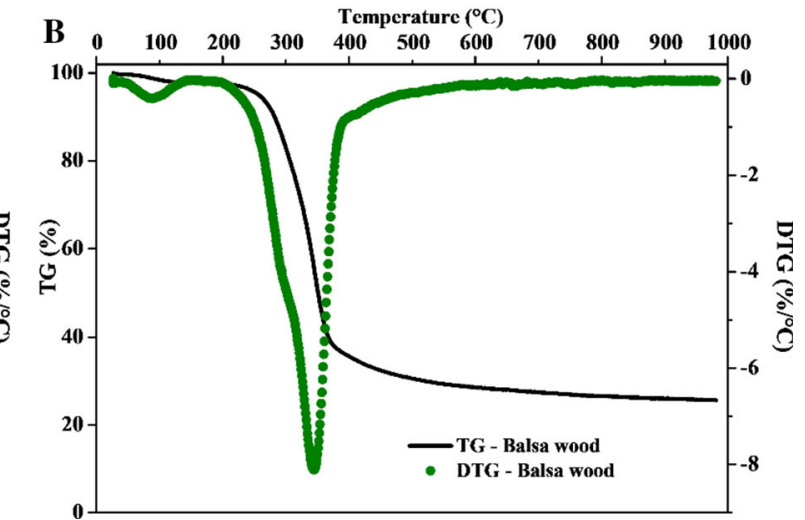

with both calcium silicates and hydration products (e.g., calcium hydroxide, calcium silicate hydrate and ettringite). In this work, accelerated carbonation was 
Table 3 The estimation of the calcium carbonate and portlandite of the particleboards under study obtained by the stoichiometry calculation

\begin{tabular}{llr}
\hline Curing condition & Calcium carbonate $(\%)$ & Portlandite $(\%)$ \\
\hline Control & 20.9 & 16.5 \\
Accelerating carbonation & 38.4 & 5.1 \\
\hline
\end{tabular}

applied after $48 \mathrm{~h}$ of the casting, i.e. several types of hydration products were affected by carbonation, mainly portlandite, as indicated in Fig. 3 and Table 3. During the accelerated carbonation curing, the $\mathrm{CO}_{2}$ is diffused and dissolved through the solid in the aqueous phase promoting the solvation of $\mathrm{CO}_{2(\mathrm{~g})}$ to $\mathrm{CO}_{2(\mathrm{aq})}$, which reacts with water or water vapor to produce $\mathrm{H}_{2} \mathrm{CO}_{3}$. The next reaction is the ionization of $\mathrm{H}_{2} \mathrm{CO}_{3}$ to $\mathrm{H}^{+}, \mathrm{HCO}^{3-}$, and $\mathrm{CO}_{3}{ }^{2-}$. The reaction between $\mathrm{HCO}_{3}{ }^{-}$and portlandite results in nucleation and precipitation of $\mathrm{CaCO}_{3}$. Precipitation of these solid phases such as the vaterite and aragonite can be formed, but these polymorphs of $\mathrm{CaCO}_{3}$ are thermodynamically less stable and revert to calcite. Amorphous calcium carbonate can be found in the final product [16]. This cyclic chemical reaction explains higher quantity of calcium carbonate than portlandite for the carbonated composites compared to the control materials.

Carbonated cement-bonded balsa particleboards have higher chemical stability considering that calcium carbonate is a more stable compound than the portlandite, which presents low solubilization resistance. Mohr et al. [29] state that the low solubilization resistance of portlandite is one of the factors that generate a higher resistance loss of vegetal reinforced composites.

Figure 4 shows the XRD patterns after the Rietveld refinement of the control (Fig. 4a) and carbonated (Fig. 4b) sample after 28 days of curing. The red line below the figures represents the residue between the XRD measurements and the calculated profile obtained by the Rietveld refinement.

The quality of the refinement can be considered by the Chi square $\left(\chi^{2}\right)$ index, which is the ratio between a factor related to difference of the calculated and experimental profile and a factor related to the data quality. Satisfactory refinements presents a $\chi^{2}$ lower than 2 [49]. As shown in Fig. 4, $\chi^{2}$ indexes of 1.5328 and 1.1347 were found for the control and carbonated particleboards respectively. The high intensity of the background is related to the presence of amorphous phases, such as CSH gel of the cement matrix and lignin of the balsa.

The crystallographic information file of each identified phase was obtained in the Crystallography Open Database (COD). In both samples, the phases alite, belite, portlandite, brownmillerite, calcium carbonate (calcite) and periclase $(\mathrm{MgO})$, which are typical phases found in cement matrix were indexed [47]. The ettringite phase was observed only in the carbonated sample.

The corresponding amounts of each phase are shown in Fig. 4. Nevertheless, the main objective in the semi-quantification of the crystalline phases in this work was to observe the effect of carbonation curing on the consumption of portlandite.

In Table 4, the comparison between the calcium carbonate and portlandite content of the control and carbonated particleboards is shown. In the carbonated particleboards, only traces of portlandite were identified, which means that the accelerated carbonation curing was effective.

As previously reported in TG-DTG analysis, the XRD results have been also noticed an increase in the amount of calcium carbonate and a decrease in the amount of portlandite for the cement-bonded balsa particleboards cured by using accelerated carbonation compared to control cement-bonded balsa particleboards.

Based on the obtained results of TG and XRD, it was possible to verify that the reaction of portlandite with $\mathrm{CO}_{2}$ resulted mostly in the formation of calcium carbonate and consequently the particleboards are denser and more chemically and dimensionally stable. This effect provides a less aggressive matrix for the balsa chips.

\subsubsection{Thermal-physical-mechanical properties}

Table 5 shows the average value of 20 specimens for each curing of the particleboards' thermal conductivity. 

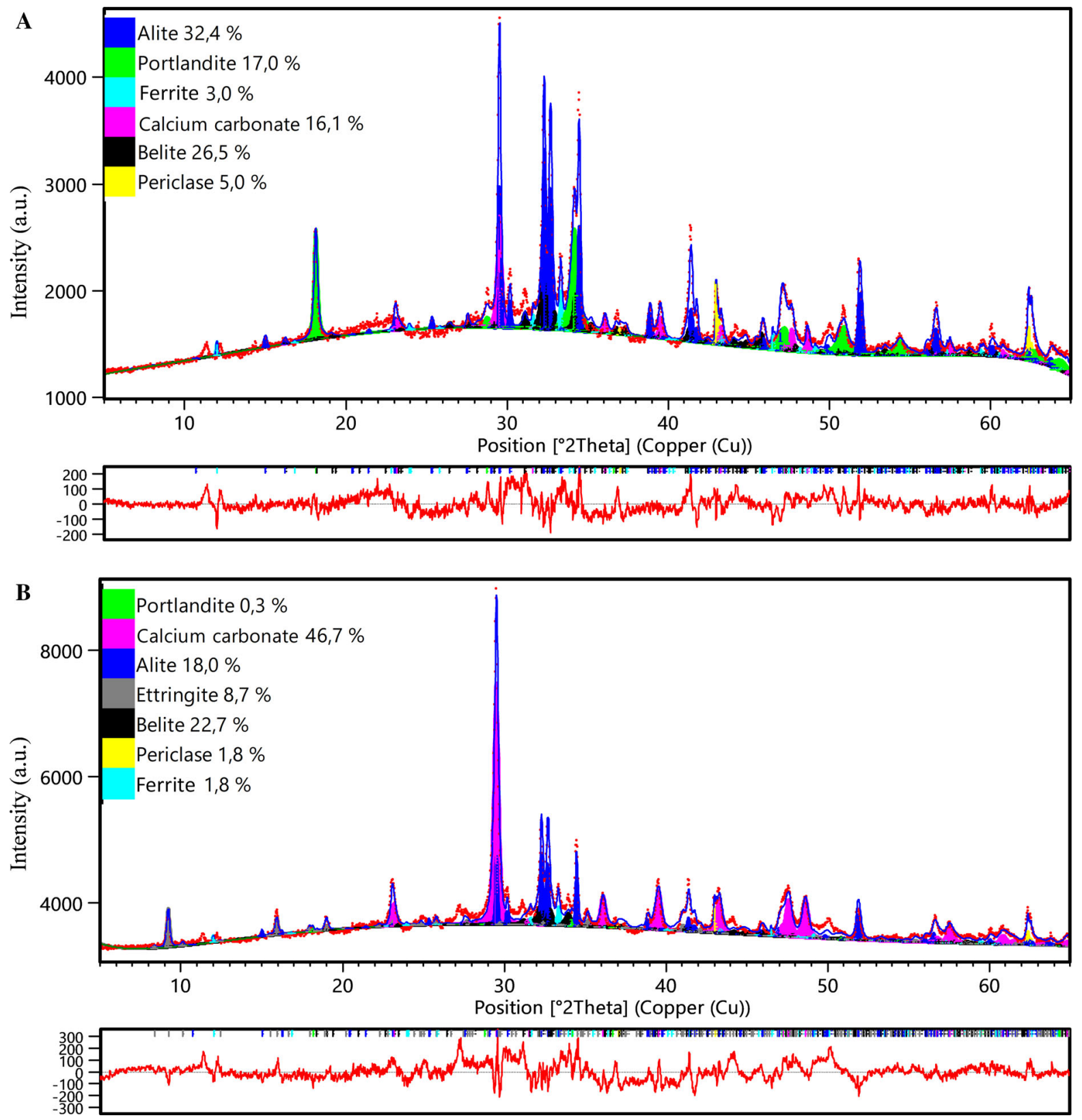

Fig. 4 XRD patterns after Rietveld refinement: a control; $\mathbf{b}$ accelerated carbonation. (Color figure online)

Table 4 Contents of calcium carbonate and portlandite of the particleboards under study obtained by the Rietveld refinement

\begin{tabular}{llr}
\hline Curing condition & Calcium carbonate $(\%)$ & Portlandite $(\%)$ \\
\hline Control & 16.1 & 17.0 \\
Accelerating carbonation & 46.7 & 0.3 \\
\hline
\end{tabular}

From Table 5, it can be seen that the thermal conductivity results of the cement-bonded balsa particleboards do not differ statistically $(p>0.05)$. The thermal conductivity mean values were 0.21 [W/ 
$(\mathrm{m} \mathrm{K})]$, these results indicate an excellent thermal insulation. The values of both cement-bonded balsa particleboards are $86 \%$ lower in comparison with conventional concrete panels $(1.52[\mathrm{~W} /(\mathrm{m} \mathrm{K})]$ with a density of $2260 \mathrm{~kg} / \mathrm{m}^{3}$ ) produced using sand ratio of 0.3 as aggregate [50].

The thermal conductivity of the cement-bonded balsa particleboard is also lower than the lightweight composite with $15 \%$ (by mass) of coconut fiber $(0.59$ [W/(m K)] with a density of $1297 \mathrm{~kg} / \mathrm{m}^{3}$ ) studied by Khedari et al. [51] and the cement-bonded particleboard produced using recycled wood $(0.29[\mathrm{~W} /(\mathrm{m} \mathrm{K})]$ with a density of $1540 \mathrm{~kg} / \mathrm{m}^{3}$ ) studied by Wang et al. [50]. In addition, these values obtained for the cementbonded balsa particleboard are lower than the required value of cement-bonded particleboards for thermal insulation as per BS EN 13986 [52], which establishes a minimum value of $0.23[\mathrm{~W} /(\mathrm{m} \mathrm{K})]$ for particleboards with density of $1200 \mathrm{~kg} / \mathrm{m}^{3}$.

The main reason for the low thermal conductivity values of the cement-bonded balsa particleboards is due to the high amount of wood used to produce these composites. According to Khedari et al. [51] the thermal conductivity in cement-bonded particleboard is a close function of wood content, once that the thermal conductivity of wood $[0.07 \mathrm{~W} /(\mathrm{m} \mathrm{K})][50]$ is lower than the cement $[0.53 \mathrm{~W} /(\mathrm{m} \mathrm{K})]$ [53]. Hence, the thermal conductivity is decreased when the content of the wood increases. However, the thermal conductivity of the particleboards does not differ of the carbonated composites compared to the control materials because mainly it depends on quantity of wood. Since the percentage of wood used to produce the composites was the same ( $30 \%$ by mass of balsa), even if there is a decrease in quantity of micropores, there is not significantly influence in the thermal conductivity values.

The average values of 40 specimens for each physical property (WA and TS) after immersion in water for $24 \mathrm{~h}$ and 40 specimens for $\mathrm{AD}$ of the control

Table 5 Thermal conductivity of the cement-bonded balsa particleboards

\begin{tabular}{ll}
\hline Curing condition & Thermal conductivity $[\mathrm{W} /(\mathrm{m} \mathrm{K})]$ \\
\hline Control & $0.21 \mathrm{a}$ \\
Accelerated carbonation & $0.21 \mathrm{a}$
\end{tabular}

Values with different letters in the same column have statistical difference from Tukey test $(p<0.05)$ and carbonated particleboards are shown in Table 6 . The results indicated that WA and TS values of the carbonated particleboard were statistically lower $(p<0.05)$ than the values obtained for the control particleboard.

Consequently, the $\mathrm{AD}$ of the carbonated particleboard has increased significantly $(p<0.05)$. This behavior can be explained by the lower number of pores in the particleboard after accelerated carbonation curing, which caused the densification interface PC-balsa chips due to the formation of calcium carbonate.

Therefore, as indicated in Table 6, the carbonation affected the values of the physical properties of the particleboard. It is worth mentioning that the physical properties of the cement-bonded balsa particleboards presented better physical characteristics compared to those produced with coconut fibers [55], Eucaliptus urophylla and Hevea. Brasiliensis [56], Leucaenaglauca, Pithecellobium dulce and Tamarixaphylla [2]. Moreover, the TS results indicated the dimensional variation of the cement-bonded balsa particleboards obtained were lower than the limits prescribed by ISO 8335 standard [54], which standardized acceptable values between 1.2 and $1.8 \%$ to the TS after immersion in water for $24 \mathrm{~h}$.

Table 7 presents the average value of 40 specimens for each mechanical property studied (MOR and MOE) and the required values of the standard ISO 8335 [54]. The results indicated that the MOR and MOE values of the carbonated particleboard were statistically higher than the values obtained for the control particleboard $(p<0.05)$.

It was also noticed that the accelerated carbonation increased by $23 \%$ of MOR and by $38 \%$ of MOE of the cement-bonded balsa particleboards. In addition, the average values of MOR and MOE of the control and carbonated particleboards produced in this study are relatively higher than the required by ISO 8335 standard [54] as shown in Table 7.

The MOR and MOE properties of the cementbonded balsa particleboards were higher than those found by Aggarwal et al. [8], who reported values of 9.61 MPa (MOR) and $3270 \mathrm{MPa}$ (MOE) for a cementbonded particleboard produced using $16 \%$ (by mass) of arhar stalks with a density of $1729 \mathrm{~kg} / \mathrm{m}^{3}$. Research conducted by Okino et al. [56] found mean values of MOR and MOE of 6.3 and $4489 \mathrm{MPa}$, respectively, in a cement-bonded particleboard produced with 
Table 6 Physical characteristics of cement-bonded balsa particleboards

\begin{tabular}{llll}
\hline Curing condition & WA 24 h $(\%)$ & TS 24 h $(\%)$ & AD $\left(\mathrm{kg} / \mathrm{m}^{3}\right)$ \\
\hline Control & $16.78 \mathrm{a}$ & $0.71 \mathrm{a}$ & $1057 \mathrm{~b}$ \\
Accelerated carbonation & $14.35 \mathrm{~b}$ & $0.59 \mathrm{~b}$ & $1239 \mathrm{a}$ \\
Specified by ISO 8335 [54] & - & $1.2-1.8$ & - \\
\hline
\end{tabular}

Values with different letters in the same column have statistical difference from Tukey test $(p<0.05)$

Table 7 MOR and MOE of the cement-bonded balsa particleboards

\begin{tabular}{lll}
\hline Curing Condition & MOR $(\mathrm{MPa})$ & MOE $(\mathrm{MPa})$ \\
\hline Control & $10.16 \mathrm{~b}$ & $5114 \mathrm{~b}$ \\
Accelerated carbonation & $12.57 \mathrm{a}$ & $7101 \mathrm{a}$ \\
ISO 8335 [54] & 9.00 & 3000
\end{tabular}

Values with different letters in the same column have statistical difference from Tukey test $(p<0.05)$

Eucalyptus Urophylla and Hevea Brasiliensis with a density of $1400 \mathrm{~kg} / \mathrm{m}^{3}$.

Cabral et al. [57] studied the MOR and MOE properties (28 days age) of the cement-bonded bagasse particleboard with different initial curing process, control and accelerated carbonation $(24 \mathrm{~h}$ with $15 \%$ concentration of $\mathrm{CO}_{2}$ ). The authors reported that the accelerated carbonation in cement-bonded bagasse particleboards resulted in better mechanical properties, showing MOR values of $3.99 \mathrm{MPa}$ (control) and $7.13 \mathrm{MPa}$ (accelerated carbonation), and MOE values of $1635 \mathrm{MPa}$ (control) and $3681 \mathrm{MPa}$ (accelerated carbonation). However, the results obtained by Cabral et al. [57] for the MOR and MOE properties were much lower than those found in the cement-bonded balsa particleboard (Table 7).

The mechanical behavior of the composite is also related to the high content of crystalline material (around 84\%) present in the balsa chips (Fig. 1b), once the high crystallinity content provides greater chemical stability of the balsa chips into a cement medium. That is, the organic compounds present in the balsa chips that can potentially harm the cement setting time did not dissociate in the aqueous medium, and morphology of the balsa can potentially increase the properties of composites.

According to Borrega et al. [10], the polygonal form of the balsa microstructure, similar to a honeycomb, the vessels and the voids of the chips structure allow the inclusion of the cement within the balsa structure. Therefore, such products can improve the interlocking between matrix and balsa chips.

\section{Conclusions}

Based on the results of this study, the following concluding remarks can be mentioned:

1. The potential usage of balsa chips as raw material to produce cement-bonded particleboards have been demonstrated.

2. TG-DTG analysis and Rietveld refinement have shown that accelerated carbonation was effective for the cement-bonded balsa particleboard after 28 days curing. Rietveld refinement has decreased by $98 \%$ of the portlandite content and have increased by $190 \%$ the calcium carbonate content of the cement-bonded balsa particleboards after accelerated carbonation curing.

3. Thermal conductivity values of the cementbonded balsa particleboards (control and accelerated carbonation) were lower than the required value by BS EN 13986 standard for wood-based particleboards.

4. The physical and mechanical results suggested that the cement-bonded balsa particleboards met the requirements established by ISO 8335 standard. The accelerated carbonation curing (accelerated carbonation) improved $23 \%$ MOR and $38 \%$ MOE average values.

Acknowledgements The authors are sincerely thankful to the Brazilian financial support from Conselho Nacional de Desenvolvimento Científico e Tecnológico (CNPq, Brazil) [Grant Nos. 464532/2014-0 and 312151/2016-0] and company Infibra S.A. Coordenação de Aperfeiçoamento de Pessoal de Nível Superior (CAPES, Brazil) and Fundação de Amparo à Pesquisa do Estado de São Paulo (FAPESP) [Grant No. 2016/07372-9]. 


\section{Compliance with ethical standards}

Conflict of interest The authors declare that there is no conflict of interest.

\section{References}

1. Frybort S, Mauritz R, Teischinger A, Müller U (2008) Cement bonded composites-a mechanical review. BioResources 3:602-626

2. Nasser RA, Salem MZM, Al-Mefarrej HA, Aref IM (2016) Use of tree pruning wastes for manufacturing of wood reinforced cement composites. Cem Concr Compos 72:246-256. https://doi.org/10.1016/j.cemconcomp.2016. 06.008

3. Kalaycioglu H, Nemli G (2006) Producing composite particleboard from kenaf (Hibiscus cannabinus L.) stalks. Ind Crops Prod 24:177-180. https://doi.org/10.1016/j.indcrop. 2006.03.011

4. Nozahic V, Amziane S (2012) Influence of sunflower aggregates surface treatments on physical properties and adhesion with a mineral binder. Compos Part A Appl Sci Manuf 43:1837-1849. https://doi.org/10.1016/j. compositesa.2012.07.011

5. Guntekin E, Karakus B (2008) Feasibility of using eggplant (Solanum melongena) stalks in the production of experimental particleboard. Ind Crops Prod 27:354-358. https:// doi.org/10.1016/j.indcrop.2007.12.003

6. Babatunde A (2011) Durability characteristics of cementbonded particleboards manufactured from maize stalk residue. J For Res 22:111-115. https://doi.org/10.1007/ s11676-011-0135-2

7. Zhou XW, Zheng F, Li HG, Lu CL (2010) An environmentfriendly thermal insulation material from cotton stalk fibers. Energy Build 42:1070-1074. https://doi.org/10.1016/j. enbuild.2010.01.020

8. Aggarwal LK, Agrawal SP, Thapliyal PC, Karade SR (2008) Cement-bonded composite boards with arhar stalks. Cem Concr Compos 30:44-51. https://doi.org/10.1016/j. cemconcomp.2007.07.004

9. Ashori A, Tabarsa T, Sepahvand S (2012) Cement-bonded composite boards made from poplar strands. Constr Build Mater 26:131-134. https://doi.org/10.1016/j.conbuildmat. 2011.06.001

10. Borrega M, Ahvenainen P, Serimaa R, Gibson L (2015) Composition and structure of balsa (Ochroma pyramidale) wood. Wood Sci Technol 49:403-420. https://doi.org/10. 1007/s00226-015-0700-5

11. Fengel D, Wegener G (2003) Wood: chemistry, ultrastructure, reactions. Verlag Kessel, Remagen

12. Hu XP, Hsieh YL (2001) Effects of dehydration on the crystalline structure and strength of developing cotton fibers. Text Res J Princet 71:231-239. https://doi.org/10. 1177/004051750107100308

13. Almeida AEFS, Tonoli GHD, Santos SF, Savastano H Jr (2013) Improved durability of vegetable fiber reinforced cement composite subject to accelerated carbonation at early age. Cem Concr Compos 42:49-58. https://doi.org/10. 1016/j.cemconcomp.2013.05.001
14. Santos SF, Schmidt R, Almeida AEFS, Tonoli GHD, Savastano H Jr (2015) Supercritical carbonation treatment on extruded fibre-cement reinforced with vegetable fibres. Cem Concr Compos 56:84-94. https://doi.org/10.1016/j. cemconcomp.2014.11.007

15. Cuéllar-Franca RM, Azapagic A (2015) Carbon capture, storage and utilisation technologies: a critical analysis and comparison of their life cycle environmental impacts. J CO2 Util 9:82-102. https://doi.org/10.1016/j.jcou.2014.12.001

16. Fernández Bertos M, Simons SJR, Hills CD, Carey PJ (2004) A review of accelerated carbonation technology in the treatment of cement-based materials and sequestration of $\mathrm{CO}_{2}$. J Hazard Mater 112:193-205. https://doi.org/10. 1016/j.jhazmat.2004.04.019

17. Borges PHR, Costa JO, Milestone NB, Lynsdale CJ, Streatfield RE (2010) Carbonation of $\mathrm{CH}$ and $\mathrm{C}-\mathrm{S}-\mathrm{H}$ in composite cement pastes containing high amounts of BFS. Cem Concr Res 40:284-292. https://doi.org/10.1016/j. cemconres.2009.10.020

18. Wang L, Chen SS, Tsang DCW, Poon C-S, Dai J-G (2017) $\mathrm{CO}_{2}$ curing and fibre reinforcement for green recycling of contaminated wood into high-performance cement-bonded particleboards. J CO2 Util 18:107-116. https://doi.org/10. 1016/j.jcou.2017.01.018

19. NBR 5733 (1991) Cimento portland com alta resistencia inicial. Rio de Janeiro, Brazil

20. Morais JPS, Rosa MF, Marconcini JM (2010) Procedimentos para análise lignocelulósica. Embrapa Algodão, p 54

21. Tappi T 222 om-88 (1988) Acid-insoluble lignin in wood and pulp

22. Tappi T 204 cm-97 (2007) Solvent extractives of wood and pulp

23. Langford JI, Wilson AJC (1978) Scherrer after sixty years: a survey and some new results in the determination of crystallite size. J Appl Crystallogr 11:102-113. https://doi.org/ 10.1107/S0021889878012844

24. French AD (2014) Idealized powder diffraction patterns for cellulose polymorphs. Cellulose 21:885-896. https://doi. org/10.1007/s10570-013-0030-4

25. Nam S, French AD, Condon BD, Concha M (2016) Segal crystallinity index revisited by the simulation of X-ray diffraction patterns of cotton cellulose $I \beta$ and cellulose II. Carbohydr Polym 135:1-9. https://doi.org/10.1016/j. carbpol.2015.08.035

26. Nishiyama Y, Langan P, Chanzy H (2002) Crystal structure and hydrogen-bonding system in cellulose $I \beta$ from synchrotron X-ray and neutron fiber diffraction. J Am Chem Soc 124:9074-9082. https://doi.org/10.1021/ja0257319

27. Hachmi M, Moslemi AA, Campbell AG (1990) A new technique to classify the compatibility of wood with cement. Wood Sci Technol 24:345-354. https://doi.org/10.1007/ BF00227055

28. Cabral MR, Nakanishi EY, Fiorelli J (2017) Evaluation of the effect of accelerated carbonation in cement-bagasse panels after cycles of wetting and drying. J Mater Civ Eng 29:04017018. https://doi.org/10.1061/(ASCE)MT.19435533.0001861

29. Mohr BJ, Biernacki JJ, Kurtis KE (2007) Supplementary cementitious materials for mitigating degradation of kraft pulp fiber-cement composites. Cem Concr Res 
37:1531-1543. https://doi.org/10.1016/j.cemconres.2007. 08.001

30. ASTM E1530 (2011) Standard test method for evaluating the resistance to thermal transmission of materials by the guarded heat flow meter technique. Philadelphia, United States

31. DIN EN 322 (1993) Wood-based panels. Determination of moisture content. Brussels, Belgium

32. DIN EN 323 (1993) Wood-based panels. Determination of density. Brussels, Belgium

33. DIN EN 310 (1993) Wood-based panels. Determination of modulus of elasticity in bending and of bending strength. Brussels, Belgium

34. Semple KE, Cunningham RB, Evans PD (2002) The suitability of five Western Australian mallee eucalypt species for wood-cement composites. Ind Crops Prod 16:89-100. https://doi.org/10.1016/S0926-6690(02)00012-2

35. Malek S, Gibson LJ (2017) Multi-scale modelling of elastic properties of balsa. Int J Solids Struct 113-114:118-131. https://doi.org/10.1016/j.ijsolstr.2017.01.037

36. Fiorelli J, Gomide CA, Lahr FAR, Nascimento MF, Sartori DL, Ballesteros JEM, Bueno SB, Belini UL (2014) Physicochemical and anatomical characterization of residual lignocellulosic fibers. Cellulose 21:3269-3277. https://doi. org/10.1007/s10570-014-0398-9

37. Fan M, Ndikontar MK, Zhou X, Ngamveng JN (2012) Cement-bonded composites made from tropical woods: compatibility of wood and cement. Constr Build Mater 36:135-140. https://doi.org/10.1016/j.conbuildmat.2012. 04.089

38. Jorge FC, Pereira C, Ferreira JMF (2004) Wood-cement composites: a review. Holz Roh Werkst 62:370-377. https://doi.org/10.1007/s00107-004-0501-2

39. Chakraborty S, Kundu SP, Roy A, Adhikari B, Majumder SB (2013) Effect of jute as fiber reinforcement controlling the hydration characteristics of cement matrix. Ind Eng Chem Res 53:1252-1260. https://doi.org/10.1021/ ie $300607 \mathrm{r}$

40. Moniruzzaman M, Ono T (2013) Separation and characterization of cellulose fibers from cypress wood treated with ionic liquid prior to laccase treatment. Bioresour Technol 127:132-137. https://doi.org/10.1016/j.biortech.2012.09. 113

41. Wikberg H, Maunu SL (2004) Characterisation of thermally modified hard- and softwoods by ${ }^{13} \mathrm{C}$ CPMAS NMR. Carbohydr Polym 58:461-466. https://doi.org/10.1016/j. carbpol.2004.08.008

42. Penttilä PA, Kilpeläinen P, Tolonen L, Suuronen JP, Sixta H, Willför S, Serimaa R (2013) Effects of pressurized hot water extraction on the nanoscale structure of birch sawdust. Cellulose 20:2335-2347. https://doi.org/10.1007/s10570013-0001-9

43. Andersson S, Wikberg H, Pesonen E, Maunu SL, Serimaa R (2004) Studies of crystallinity of Scots pine and Norway spruce cellulose. Trees Struct Funct 18:346-353. https://doi. org/10.1007/s00468-003-0312-9
44. Correia VC, Santos V, Sain M, Santos SF, Leão AL, Savastano H Jr (2016) Grinding process for the production of nanofibrillated cellulose based on unbleached and bleached bamboo organosolv pulp. Cellulose 23:2971-2987. https://doi.org/10.1007/s10570-016-0996-9

45. Borrega M, Gibson LJ (2015) Mechanics of balsa (Ochroma pyramidale) wood. Mech Mater 84(75-90):015. https://doi. org/10.1016/j.mechmat.2015.01.014

46. Rostami V, Shao Y, Boyd AJ, He Z (2012) Microstructure of cement paste subject to early carbonation curing. Cem Concr Res 42:186-193. https://doi.org/10.1016/j. cemconres.2011.09.010

47. Taylor HFW (1997) Cement chemistry. ThomasTelford, London

48. Pizzol VD, Mendes LM, Frezzatti L, Savastano H Jr, Tonoli GHD (2014) Effect of accelerated carbonation on the microstructure and physical properties of hybrid fiber-cement composites. Miner Eng 59:101-106. https://doi.org/ 10.1016/j.mineng.2013.11.007

49. Young R (1993) The rietveld method. Oxford University Press, London

50. Wang L, Chen SS, Tsang DCW, Poon CS, Shih K (2016) Value-added recycling of construction waste wood into noise and thermal insulating cement-bonded particleboards. Constr Build Mater 125:316-325. https://doi.org/10.1016/j. conbuildmat.2016.08.053

51. Khedari J, Suttisonk B, Pratinthong N, Hirunlabh J (2001) New lightweight composite construction materials with low thermal conductivity. Cem Concr Compos 23:65-70. https://doi.org/10.1016/S0958-9465(00)00072-X

52. BSI, BS EN 13986 (2004) Wood-based panels for use in construction-characteristics, evaluation of conformity and marking

53. Xu Y, Chung DDL (2000) Effect of sand addition on the specific heat and thermal conductivity of cement. Cem Concr Res 30:59-61. https://doi.org/10.1016/S00088846(99)00206-9

54. ISO 8335 (1987) Cement-bonded particleboards-boards of Portland or equivalent cement reinforced with fibrous wood particles. Switzerland

55. Ferraz JM, Menezzi CHS, Teixeira DE, Martins SA (2011) Effects of treatment of coir fiber and cement/fiber ratio on properties of cement-bonded composites. BioResources 6:3481-3492. https://doi.org/10.15376/biores.6.3.34813492

56. Okino EYA, Souza MR, Santana MAE, Alves MVS, Sousa ME, Teixeira DE (2004) Cement-bonded wood particleboard with a mixture of eucalypt and rubberwood. Cem Concr Compos 26:729-734. https://doi.org/10.1016/S09589465(03)00061-1

57. Cabral MR, Nakanishi EY, Fiorelli J (In press) Cementbonded panels produced with sugarcane bagasse cured by accelerated carbonation. J Mater Civ Eng. https://doi.org/ 10.1061/(ASCE)MT.1943-5533.0002301 